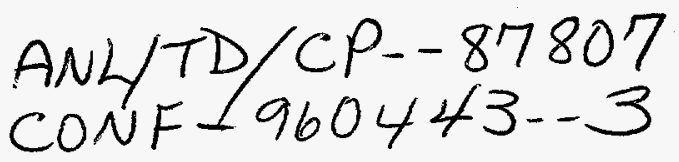

\title{
Particle Prediction from Plasma Torch Cutting on Stainless Steel, Carbon Steel, and Aluminum
}

\section{J. Novick, J. Nasiatka, C.J. Brodrick, S. J. Crawford,}


appropriate cutting tool for the job, and the necessary pollution controls required, including filtering, personal protection, and air monitoring.

Laboratory cutting tests are conducted inside of a closed, filtered chamber where a remotely activated cutting tool is held stationary as the material is moved past it at a constant speed. The aerosols generated by the cutting process are collected by a High Efficiency Particulate Air (HEPA) filter. The particulate size distributions are determined by isokinetically sampling the exhaust duct using a cascade impactor. The mass median aerodynamic diameter (MMAD) is calculated for reference in the database. Secondary waste (slag and dross) is collected in a pan underneath the cutting head, while any loose particles are collected with a HEPA filter equipped vacuum. Currently, laboratory tests have been completed using a 100 Amp Plasma Arc Torch to cut Carbon Steel, Stainless Steel, and Aluminum.

A plasma torch cut produces particles by condensation of metal vapors, and droplet formation from liquid metal shear forces. The measured particle size distribution for a particular cut is determined by a complex interaction between the rate of energy input (torch power and cutting speed) and the flow of the cutting gas (pressure, flow, nozzle size, and kerf width). In general, as energy input increases, either through higher torch power or slower cutting speed, the temperature of the cut is increased and so is the quantity of metal vaporized. Higher energy input also increases the kerf size, which results in a lower gas velocity. This decreases the atomization of the molten metal. At this time the cutting process is affected by too many variables, and so the particle size distribution and quantity for a given cut cannot be predicted and must be measured.

Most measured particle size distributions are bimodal with one mode at about .2 microns, attributed to the condensation of metal vapors, and the other at about 10 microns, attributed to the atomization of the molten metal. Because of the plasma torch operating conditions of relatively high temperature and relatively low gas flow, the resulting MMAD's are typically less than .5 microns.

In order to provide an empirical prediction of the aerosol quantity produced, a testing plan consistent with the principles of risk assessment was devised to determine the worst case scenario in terms of maximum aerosol production for a given material. This was done by determining the cutting torch power, and then the cutting speed at that power that generate the maximum level of aerosols. Once these parameters were defined, varying length cuts were made on samples of different thickness' typically used, and the quantity of aerosols generated was plotted against the length $\mathrm{x}$ the thickness of cut. 
The levels of maximum aerosol generation on 3/8" thick samples were found at 80 Amps power and 5 $\mathrm{mm} / \mathrm{s}(.2 \mathrm{in} / \mathrm{sec})$ speed for carbon steel, 100 Amps and $2.5 \mathrm{~mm} / \mathrm{s}(.1 \mathrm{in} / \mathrm{s})$ for stainless, and 100 Amps at 4 $\mathrm{mm} / \mathrm{s}(.16 \mathrm{in} / \mathrm{s})$ for aluminum. Varying length and thickness cuts showed no observable dependance on material thickness for carbon steel as seen in Figure 1, but revealed that both stainless and aluminum samples do appear to have some dependance on thickness, with thinner materials producing more aerosols.

Information collected from the laboratory scale cutting with the Plasma Torch has been compiled and entered into the database along with the available information from outside sources that contain information on the aerosols produced, the MMAD, along with the length and thickness of the material being cut. OxyAcetylene torch and $\mathrm{CO}_{2}$ laser cuts are planned for FY96, and additional information on other tools will be added as it becomes available.

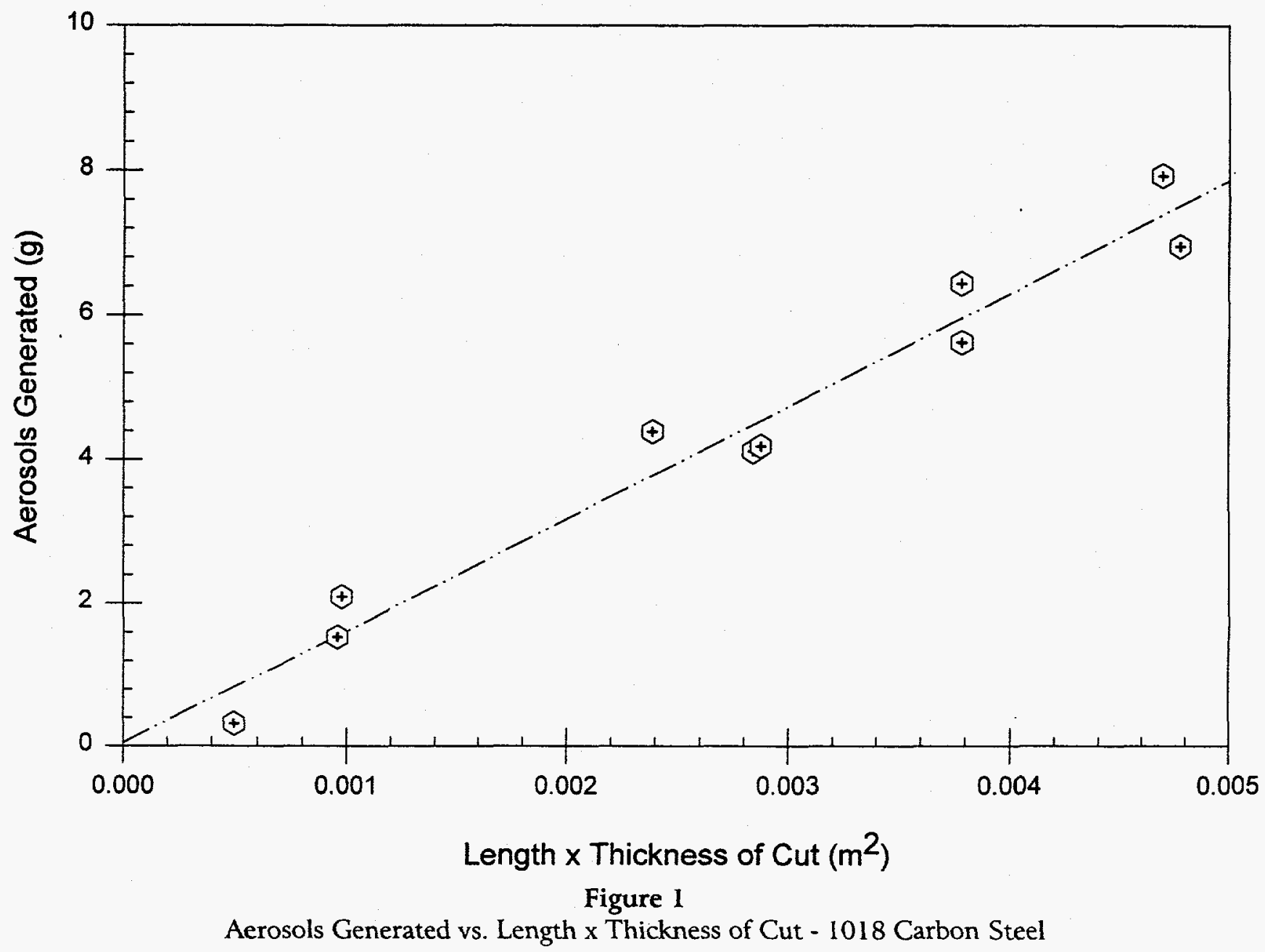




\section{References}

${ }^{1}$ Bach W., H. Steiner, G. Schreck, and G. Pilot, "Analysis of results obtained with different cutting techniques and associated filtration systems for the dismantling of radioactive metallic components." Comission of European Communities, Report EUR14213, 1993.

${ }^{2}$ Baston V., K. Hoffsteter, and R. Karuhn, "Characterization of Reaction Gases and Aerosols From Underwater Plasma Arc Cutting Demonstration Test at Three Mile Island," Nuclear Technology, Vol. 83, pp. 216-237, 1988

${ }^{3}$ T. Nishizono, Y. Ikezawa, "Characteristics of Aerosol Generated during the JPDR Decommissioning," Proceeding of the 12th ISCC in Yokohama, 1994

${ }^{4}$ K.H. Schaller, B. Huber, Decommissioning of Nuclear Power Plants, Graham \& Trotman Ltd., 1984

${ }^{5}$ W. Bach, H Steiner, G. Pilot, E. Skupinski, “Analysis of Results Obtained with Different Cutting Techniques and Associated Filtration Systems for the Dismantling of Radioactive Metallic Components", Decommissioning of Nuclear Installations, pp $659-665,1990$

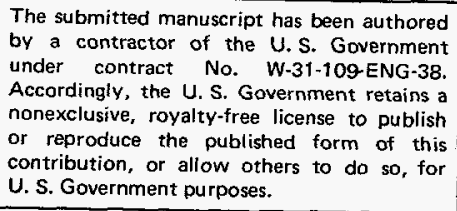

\section{DISCLAIMER}

This report was prepared as an account of work sponsored by an agency of the United States Government. Neither the United States Government nor any agency thereof, nor any of their employees, makes any warranty, express or implied, or assumes any legal liability or responsibility for the accuracy, completeness, or usefulness of any information, apparatus, product, or process disclosed, or represents that its use would not infringe privately owned rights. Reference herein to any specific commercial product, process, or service by trade name, trademark, manufacturer, or otherwise does not necessarily constitute or imply its endorsement, recommendation, or favoring by the United States Government or any agency thereof. The views and opinions of authors expressed herein do not necessarily state or reflect those of the United States Government or any agency thereof. 